\title{
Evaluation of Hypoglycemic Activity of Opuntia dillenii Haw Fruit Juice in Streptozotocin-Induced Diabetic Rats
}

\author{
Inas Z.A. Abdallah \\ Nutrition and Food Science Dept., Faculty of Home Economics \\ Helwan University
}

\begin{abstract}
:
Background: Opuntia dillenii Haw fruit is used in folk medicine as an antidiabetic agent. The aim of this study was to evaluate the possible curative role of $O$. dillenii fruit juice using the streptozotocin (STZ)-induced diabetic rats. The nutritive value of the edible portion of the fruit was also assessed.

Results: The results showed that $O$. dillenii fruit is a rich source of fiber, carbohydrates, vitamins $\mathrm{B}_{1}, \mathrm{~B}_{2}$ and $\mathrm{C}$, in addition to the minerals, $\mathrm{Fe}, \mathrm{Zn}, \mathrm{Cu}, \mathrm{Cr}, \mathrm{Mn}, \mathrm{Ca}$, and $\mathrm{Mg}$. Biological results showed that intraperitoneal injection with STZ caused highly significant reduction in body weight gain\%, highly significant elevation in blood glucose concentration accompanied by significant reduction in liver glycogen cotent as compared with control group. Diabetic rats also revealed significant elevation in lipid peroxide (MDA) level, highly significant elevation in total cholesterol (TC), triacylglycerols (TAG), low-density lipoprotein cholesterol (LDL-C) and very low-density lipoprotein cholesterol (VLDL-C) concurrent with highly significant reduction in high-density lipoprotein cholesterol (HDL-C) as compared with control group. Oral administration of $O$. dillenii juice had no effect on normal rats. Meanwhile, oral administration of $O$. dillenii juice to diabetic rats induced siginficant improvement in body weight gain $\%$ and lipid profile, it reduced significantly blood glucose and MDA levels as compared with non treated diabetic group. Histopathological investigation of the pancreatic tissue of STZ-diabetic rats represented the presence of necrosis, edema and congested blood vessels in the islets of Langerhans cells. $O$. dillenii fruit juice treatment overcome the previous changes, the majority of the cells tend to be normal.The improvement in the cells of Langerhans islets may explain the antidiabetic effect of the fruit juice under study. It also may improve the insulin receptors of $\beta$ cells.
\end{abstract}

Conclusion: It could be concluded that $O$. dillenii fruit juice had a potent hypoglycemic activity, this effect may be attributed to its antioxidant activity and its high content of chromium which was proved in this study. Therefore, it could be recommended that $O$. dillenii should be ingested as fresh fruit to diabetic and hypercholesterolemic patients beside the usual therapy.

Key words: Opuntia dillenii Haw fruit juice, Nutritive value, Hypoglycemic activity, Streptozotocin, Diabetic rats.

\section{Introduction}

Diabetes mellitus, a metabolic disorder, is characterized by hyperglycemia, altered metabolism of lipids, carbohydrates and proteins with an increased risk of complications of vascular diseases (Petrovsky and Schatz, 2003). Chronic hyperglycemia during diabetes causes permanent tissue damage, notably to the retinas, kidneys and nerve endings (American Diabetes Association, 2007). These may be delayed, decreased or prevented by maintaining blood glucose values close to normal. The increasing number of aging population, consumption of calories rich diet, obesity and sedentary life style have lead to tremendous increase in the number of diabetics worldwide (Wild et al., 2004). According to WHO projections, the prevalence of diabetes is likely to increase by $35 \%$. Currently there are over 150 million diabetics worldwide and this is likely to increase to 300 million or more by the year 2025 (Boyle et al., 2001).

It is apparent that due to the side effects of the currently used drugs, there is a need for safe agents with minimal adverse effects, which can be taken for long duration. Recently, the search for appropriate hypoglycemic agents has been 
focused on plants used in traditional medicine, partly because of the fact that natural products may be better treatments than currently used drugs (Rates, 2001). Many plants were reported to be useful for the treatment of diabetes mellitus. In Canary Islands folk medicine, Opuntia dillenii Haw fruit is used as antidiabetic agent (Perfumi and Tacconi, 1996). Cactus plants are commonly cultivated as ornamentals, some are valued for their edible fruits, others are grown as hedges, while few are used in herbal medicine. Family Cactaceae comprises about 50-150 genera, among which is the genus Opuntia which comprises about 250 species (Zomlefer, 1994 and Evans,2002).

O. dillenii (Ker-Gawl) Haw (family Cactaceae) commonly known as pear bush, prickly pear, mal rachette or tuna, is a succulent shrub growing under desert and dry conditions. It is native to American continent and the West Indies, but recently due to cultivation, it becomes widely distributed throughout Canary Islands, Southern and Eastern Africa, Pakistan, India and Australia (Ross, 1976 and Loro et al., 1999). It has been introduced in Egypt as an ornamental and medicinal plant in the Orman Botanical Garden. Opuntia species are rich source of dietary fibers, natural colorants and antioxidant vitamins and therefore, used as a food because of their edible fruit (Saenz, 2002). Pharmacological evaluation of Opuntia has shown its efficacy as antihyperlipidemic, antiatherosclerotic (Choi et al., 2002), antiviral (Ahmed et al., 1996), anti-inflammatory (Park et al., 2001), antidiabetic (Tao et al., 2005), antioxidant and antiulcerogenic agent (Galati et al., 2003). It has also been reported to protect nerve cells and used for the treatment of Alzaheimer's disease, Parkinson's disease and stroke (Saleem et al., 2005). In recent years, there has been a global trend toward the use of natural phytochemicals present in natural resources, such as fruits, vegetables and herbs, as antioxidants and functional foods (Kitts et al., 2000).

Functional components, such as dietary fiber, and antioxidant vitamins, are some of the nutrients which people use in their daily diet. Therefore, the objective of this study was to evaluate the beneficial effect of $O$. dillenii fruit juice on biological, metabolic and antioxidant disorders in streptozotocin induced diabetic rats. The nutritive value of the edible fruit was also assessed.

\section{Material And Methods}

\section{Material \\ Plant material}

Plant material was collected in October (2006) from Orman Botanical Garden, Giza, Egypt and identified by Prof. Dr. K.H. Al-Batanony, Professor of Taxonomy, Faculty of Science, Cairo University. Fresh ripe fruit was used in this study.

\section{Drugs and Chemicals}

Streptozotocin (STZ) was purchased from Sigma Chemical Co.(St Louis, Mo, USA). Starch and corn oil were obtained from local market. Casein, vitamins, minerals, sucrose and cellulose were obtained from El-Gomhoriya Pharm. and Chem. Ind. Co. Cairo, Egypt.

\section{Experimental animals}

Thirty two adult male albino rats of Sprague Dawely strain, weighing (130 \pm $5 \mathrm{gm})$ were used for this study. They were kept in the animal house (National Research Center, Dokki, Egypt) for one week for proper acclimatization before starting the experiment under the same controlled laboratory conditions of illumination, temperature and ventilation. They were housed in stainless steel cages, maintained on standard casein diet (Reeves et al., 1993) and water ad libitum throughout the experimental period.

\section{Methods}

\section{Nutritive value}

$O$. dillenii fresh ripe fruit was peeled. The edible portion was cut into pieces and dried by the hybrid solar convective drying system, belonging to the solar Energy Dept., National Research Center, Dokki, Egypt, at $30-40^{\circ} \mathrm{C}$. The dried edible portion was ground.

\section{Chemical analysis}

Chemical analysis of the edible portion of the fruit was carried out 
according to A.O.A.C International (2000).This was done in the Regional Center for Food and Feed, Agriculture Research Center, Giza, Egypt. Analysis included the determination of moisture, crude protein, crude fat, crude fiber and ash. While, total carbohydrates content were calculated by difference.

\section{Study of the mineral content}

The dried, powdered edible portion of the fruit was analyzed for micronutrients and macronutrients content. This determination was performed according to A.O.A.C International (2006) in the Regional Center for Food and Feed, Agriculture Research Center, Giza, Egypt. using atomic absorption spectrophotometer against standard elements.

\section{Study of the vitamin content}

Vitamins $\mathrm{B}_{1}, \mathrm{~B}_{2}, \mathrm{C}, \beta$ - carotene, $\mathrm{E}$ and $\mathrm{D}_{3}$ were determined in the fresh edible portion of the fruit by HPLC in the Regional Center for Food and Feed, Agriculture Research Center, Giza, Egypt. Vitamin $\mathrm{B}_{1}$ was determined adopting the thiochrome fluorometric procedure, whereas vitamin $\mathrm{B}_{2}$ was determined adopting the fluorometric method (National Food Agency of Denmark, 1996a). Vitamin C content was determined using the following conditions: suppelco RP $\mathrm{C}_{18}(5 \mu \times 250 \times 4.6 \mathrm{~mm})$ using acetate buffer as a mobile phase at a flow rate $1 \mathrm{ml} / \mathrm{min}$. UV detection was set at $\lambda \max 247 \mathrm{~nm}$ (National Food Agency of Denmark, 1996b). Vitamin A ( $\beta$-carotene) and vitamin $\mathrm{E}$ were determined by using the following conditions: Si $60,5 \mu \mathrm{m}$ x 250 x $4.6 \mathrm{~mm}$, n-heptaneisopropanol mixture flow rate $1 \mathrm{ml} / \mathrm{min}$. UV detection of vitamin $E$ was set at $292 \mathrm{~nm}$. Visible detection of $\beta$ carotene was set at 450 nm (National Food Agency of Denmark, 1996c).Vitamin $D_{3}$ was determined by using the following conditions: suppelco $\mathrm{C}_{18}(5 \mu \mathrm{x}$ $250 \times 4.6 \mathrm{~mm}$ ) using methanol acetonitrile as a mobile phase at a flow rate $1.5 \mathrm{ml} / \mathrm{min}$. UV detection was set at $\lambda \max 265 \mathrm{~nm}$ (National Food Agency of Denmark, 2001).

\section{Preparation of the fruit juice}

Opuntia dillenii Haw fresh ripe fruit was peeled (freed from cuticle and epidermis), then crushed in a Braun blender without using water. The palatable dense, red juice obtained was carefully filtered and then frozen until
use.The juice was orally administered to the animals by an intragastric gavage.

\section{Induction of diabetes}

Diabetes was experimentally induced by using a single intraperitoneal (i.p.) injection of $50 \mathrm{mg} / \mathrm{kg}$ body weight $\mathrm{STZ}$ dissolved in $0.2 \mathrm{ml}$ of $0.05 \mathrm{M}$ citrate buffer $\mathrm{pH}: 4.5$ according to Lutz and Pardridge (1993). Diabetic rats were supplied with 5\% sucrose solution orally for the first $48 \mathrm{~h}$., after STZ injection to minimize death from hypoglycemia (Peschke et al., 2000). Seventy-two h., later, blood samples were obtained by puncture of retro-orbital plexus with a fine capillary glass tube and blood glucose concentrations were determined to confirm induction of diabetes. Animals with blood glucose levels $>300 \mathrm{mg} / \mathrm{dl}$ were considered diabetic and used for the experiment.

\section{Experimental design}

After acclimatization period, rats were randomly divided into four groups, each of eight rats as follows:

Group 1: Conrol group, rats i.p. injected with $0.2 \mathrm{ml}$ of $0.05 \mathrm{M}$ citrate buffer $\mathrm{pH}: 4.5$ (negative control).

Group 2: Diabetic rats (positive control).

Group 3: $O$. dillenii fruit juice group, rats i.p. injected with citrate buffer as in group (1), $72 \mathrm{~h}$., later they received a daiy oral dose of the fruit juice at a dose level of $5 \mathrm{ml} / \mathrm{kg}$ body weight according to Perfumi and Tacconi (1996).

Group 4: Diabetic rats treated with $O$. dillenii fruit juice at the same dose in group (3).

The experiment lasted for four weeks starting from $O$. dillenii fruit juice administration. Food intake was recorded daily and animals were weighed once weekly. At the end of the experimental period, rats were deprived of food overnight. After ether anesthesia, blood samples were collected from hepatic portal vein in centrifuge tubes, left to clot and the supernatant sera were separated after centrifugation for $10 \mathrm{~min}$., at 3000 r.p.m. for biochemical analysis.The pancreas tissues were collected immediately after scarification of rats in all groups and fixed in $10 \%$ formalin and prepared for histopathological examination. 


\section{Biochemical analysis}

Separated serum samples were used for determination of glucose (Trinder, 1969), malondialdehyde (MDA) (Yoshioka et al., 1979), total cholesterol (TC) (Allain et al., 1974), high density lipoprotein cholesterol (HDL-C) (Lopes-Virella et al., 1977) and triacylglycerols (TAG) (Fossati and Prencipe,1982).While,low-density lipoprotein cholesterol (LDL-C) and very low-density lipoprotein cholesterol (VLDL-C) were calculated according to the equation of Friedwald et al. (1972). Glycogen content in liver was determined according to the method of Hassid and Abraham (1957).

\section{Histopathological examination}

Specimens from pancreas were fixed immediately in $10 \%$ neutral buffered formalin, dehydrated in different grades of alcohol, cleared in xylol, embedded in paraffin wax, sectioned at 4-6 $\mu$ thick and stained with Haematoxylin and Eosin (Bancroft et al., 1996) and examined microscopically.

\section{Statistical analysis}

Results were expressed as mean \pm SE.

Data were statistically analyzed for variance using one way analysis of variance (ANOVA) according to Snedecor and Cochron (1989). An IBM computer with a software system SPSS version 15 was used for these calculations.

\section{Results}

\section{Chemical characterization and nutritive profile of the fruit}

Chemical analysis of the edible portion of $O$. dillenii fruit is illustrated in Table (1). It included the determination of moisture, crude protein, crude fat, crude fiber, ash and total carbohydrates. The edible portion of $O$. dillenii fruit appeared to be rich in mineral elements (Table 2). Regarding micronutrients, the edible portion showed high contents of $\mathrm{Fe}, \mathrm{Zn}$ and $\mathrm{Cu}$ being much higher than $100 \%$ of the RDA and high contents of $\mathrm{Cr}$ and Mn being much higher than $100 \%$ of the AI. For macronutrients, the edible portion showed to be rich source of $\mathrm{Ca}(65 \%-78 \%$ of the $\mathrm{AI})$ and $\mathrm{Mg}$ (58.8\%-79.7\% of the RDA). In addition, $\mathrm{Na}$ and $\mathrm{K}$ were present in appreciable amounts representing 24.9\%$28.7 \%$ and $40.2 \%$ of the AI for $\mathrm{Na}$ and $\mathrm{K}$ respectively. Table (3) revealed that the edible portion of the fruit was shown to be rich in vitamins $\mathrm{B}_{1}, \mathrm{~B}_{2}$ representing $50 \%$ $54.5 \%$ and $53.8 \%-63.6 \%$ of the RDA, respectively. The content of vitamin $\mathrm{C}$ was $36 \pm 0.88 \mathrm{mg} / 100 \mathrm{~g}$ representing $40 \%-48 \%$ of the RDA. On the other hand, fat soluble vitamins ( $\beta$ - carotene and vitamin $\mathrm{E}$ ) were detected in trace amounts.

\section{Biological results}

The effect of oral administration of $O$. dillenii fruit juice on biological parameters (body weight gain\%, food intake and food efficiency ratio (FER) in normal and diabetic rats is represented in Table (4). There were highly significant decrease in body weight gain $\%$ in diabetic group as compared with control group. Administration of $O$. dillenii juice to normal rats did not influence on body weight gain\%, there was no difference as compared with control group. Treatment of diabetic rats with $O$. dillenii juice induced noticeable increase in body weight gain\%, there was significant difference between diabetic group and diabetic group treated with $O$. dillenii juice in body weight gain $\%$.

Regarding food intake and FER, diabetic rats showed non-significant change in food intake meanwhile, FER showed highly significant decrease compared with control group. $O$. dillenii fruit juice group showed slightly increase in food intake when compared with control group, the value of FER tended to match control value. Administration of $O$. dillienii juice to diabetic group showed noticeable improvement in FER as compared with diabetic group, there was significant difference between diabetic treated and non treated groups.

\section{Biochemical results}

Table (5) revealed that diabetic rats showed significant elevation in lipid peroxide content meanwhile, $O$. dillenii fruit juice group showed non-significant change in MDA content compared with control group. On the other hand, treatment of diabetic rats with $O$. dillenii juice 
showed amelioration in MDA content, its value tended to decrease as compared with non treated diabectic rats.

Data illustrated in table (5) also revealed that serum glucose concentration in diabetic rats showed highly significant elevation accompanied by significant reduction in liver glycogen content as compared with control group. Administration of $O$. dillenii juice to normal rats revealed non significant changes in serum glucose concentration and liver glycogen content, their values tended to match with the control values. Administration of $O$. dillenii juice to diabetic rats ameliorated the elevation in glucose concentration and the reduction in liver glycogen content, there was significant difference in glucose concentration between treated and non treated diabetic groups.

As shown in Table (6) there were highly significant elevation in TC, TAC, LDL-C, VLDL-C and LDL/HDL-C ratio concurrent with highly significant reduction in HDL-C in diabetic group as compared with control group. Administration of $O$. dillenii fruit juice to normal rats induced non-significant changes in all tested lipids parameters compared with control rats.
Treatment of diabetic rats with $O$. dillenii juice recorded significant improvement in all tested lipid parameters when compared with diabetic group.

\section{Histopathological results}

Microscopical examination of the pancreas tissues from control and normal rats administered $O$. dillenii fruit juice revealed normal islets of Langerhans and pancreatic acini (Fig.1\&2). The islets of Langerhans cells in pancreas tissue of streptozotocin diabetic rats showed necrosis and surrounded by mononuclear inflammatory cells infiltration and congested blood vessels (Fig.3). While, (Fig.4) presented edema of the islets of Langerhans which showed necrosis and some cells showed pyknotic nuclei. Oral administration of $O$. dillenii fruit juice to $\mathrm{STZ}$ diabetic rats improved the previous changes and partially reversed the damage caused by STZ to pancreas after four weeks of treatment. The majority of the cells consisting the islets of Langerhans in pancreas tissue of diabetic rats treated with $O$. dillenii fruit juice were normal but few cells showed necrosis and some cells contained pyknotic nuclei as illustrated in (Fig.5\&6).

Table (1): Chemical analysis of the edible portion of $O$. dillenii fruit

\begin{tabular}{|l|l|}
\hline Item & Percentage \% \\
\hline$* *$ Moisture & $83.00 \pm 0.33$ \\
\hline *Crude protein & $7.80 \pm 0.20$ \\
\hline *Crude fat & $4.20 \pm 0.02$ \\
\hline *Crude fiber & $29.48 \pm 0.29$ \\
\hline *Ash & $4.14 \pm 0.07$ \\
\hline *Total carbohydrates & $54.38 \pm 0.54$ \\
\hline
\end{tabular}

Each value represents the mean of 3 replications and expressed as mean $\pm \mathrm{SE}$.

- * $=\%$ on dry weight basis.

- ** $=\%$ on fresh weight basis.

- Data can be converted from dry weight to fresh weight by multiplying by (17/100). 
Table (2): Mineral content of the edible portion of $O$. dillenii fruit.

\begin{tabular}{|c|c|c|c|c|c|}
\hline Micronutrients & $\begin{array}{l}\text { Concentration } \\
\text { Mg/100g DW }\end{array}$ & $\begin{array}{c}\text { RDA }^{\mathrm{a}} \text { and } \mathrm{AI}^{\mathrm{b}} \\
\text { For adults } \\
\text { (amount/day) }\end{array}$ & Macronutrients & $\begin{array}{c}\text { Concentration } \\
\text { mg/100g DW }\end{array}$ & $\begin{array}{l}\text { RDA }^{\mathrm{a}} \text { and AI } \\
\text { For adults } \\
\text { (amount/day }\end{array}$ \\
\hline Iron (Fe) & $8.65 \pm 0.10$ & $8-18^{\mathrm{a}} \mathrm{mg}$ & Calcium (Ca) & $780.10 \pm 9.58$ & $1000-1200^{b} \mathrm{mg}$ \\
\hline Zinc (Zn) & $9.52 \pm 0.49$ & $8-11^{\mathrm{a}} \mathrm{mg}$ & Sodium (Na) & $373.25 \pm 5.51$ & $1300-1500^{\mathrm{b}} \mathrm{mg}$ \\
\hline Copper $(\mathbf{C u})$ & $2.09 \pm 0.004$ & $0.9^{\mathrm{a}} \mathrm{mg}$ & Potassium (K) & $1890 \pm 16.74$ & $4700^{b} \mathrm{mg}$ \\
\hline Chromium (Cr) & $0.064 \pm 0.004$ & $0.02-0.035^{\mathrm{b}} \mathrm{mg}$ & Magnesium (Mg) & $246.95 \pm 9.96$ & $310-420^{\mathrm{a}} \mathrm{mg}$ \\
\hline Manganese (Mn) & $7.84 \pm 0.002$ & $1.8-2.3^{\mathrm{b}} \mathrm{mg}$ & & & \\
\hline
\end{tabular}

- $\quad$ Each value represents the mean of 3 replications and expressed as mean \pm SE.

- $\quad$ DW $=$ Dry weight.

- ${ }^{\mathrm{a}} \mathrm{RDA}=$ Recommended dietary allowances.

- $\quad{ }^{\mathrm{b}} \mathrm{AI}=$ Adequate intakes (Food \& Nutrition Board, 2004).

Table (3): Vitamin content of the fresh edible portion of $O$. dillenii fruit.

\begin{tabular}{|c|c|c|}
\hline Vitamin & Content/ 100g FW & $\begin{array}{c}\mathbf{R D A}^{\mathbf{a}} \text { and }^{\mathbf{A I}}{ }^{\mathbf{b}} \text { for adults } \\
\text { (amount/day) }\end{array}$ \\
\hline $\mathbf{B}_{\mathbf{1}}$ & $0.60 \pm 0.03 \mathrm{mg}$ & $1.1-1.2^{\mathrm{a}} \mathrm{mg}$ \\
\hline $\mathbf{B}_{\mathbf{2}}$ & $0.70 \pm 0.03 \mathrm{mg}$ & $1.1-1.3^{\mathrm{a}} \mathrm{mg}$ \\
\hline $\mathbf{C}$ & $36.00 \pm 0.88 \mathrm{mg}$ & $75-90^{\mathrm{a}} \mathrm{mg}$ \\
\hline $\boldsymbol{\beta}$-carotene & $0.40 \pm 0.01 \mu \mathrm{g}$ & $700-900^{\mathrm{a}} \boldsymbol{\mu g}$ \\
\hline $\mathbf{E}$ & $0.002 \pm 0.0003 \mathrm{mg}$ & $15^{\mathrm{a}} \mathrm{mg}$ \\
\hline $\mathbf{D}_{\mathbf{3}}$ & Undetected & \\
\hline
\end{tabular}

- Each value represents the mean of 3 replications and expressed as mean \pm SE.

- FW = Fresh weight.

${ }^{-\mathrm{a}} \mathrm{RDA}=$ Recommended dietary allowances.

- ${ }^{\mathrm{b}} \mathrm{AI}=$ Adequate intakes (Food \&Nutrition Board, 2004).

Table (4): Effect of oral administration of $O$. dillenii fruit juice on body weight gain, food intake and food efficiency ratio (FER) in normal and diabetic rats.

\begin{tabular}{|l|c|c|c|c|}
\hline \multicolumn{1}{|c|}{ Groups } & Control & Diabetic & $\begin{array}{c}\text { O. dillenii } \\
\text { fruit juice }\end{array}$ & $\begin{array}{c}\text { Diabetic }+ \\
\text { o. dillenii fruit } \\
\text { juice }\end{array}$ \\
\cline { 1 - 3 } Body weight gain \% & $36.65 \pm 3.21$ & $13.93 \pm 1.90^{* * a}$ & $37.80 \pm 3.51$ & $28.03 \pm 3.06$ \\
\hline Food intake (g/day/group) & $91.33 \pm 3.26$ & $98.27 \pm 2.99$ & $92.90 \pm 2.32$ & $88.58 \pm 2.02$ \\
\hline FER & $0.151 \pm 0.013$ & $0.047 \pm 0.006^{* * a}$ & $0.151 \pm 0.008$ & $0.120 \pm 0.017$ \\
\hline
\end{tabular}

- Each value represents the mean of 8 rats \pm SE.

- * Significant difference from control group at $p<0.05$ and ** highly significant difference from control group at $\mathrm{p}<0.01$.

- a: Significant difference between diabetic group and diabetic group treated with $O$. dillenii fruit juice at $\mathrm{p}<0.05$. 
Table (5): Effect of oral administration of $O$. dillenii fruit juice on serum lipid peroxide as malondialdehyde (MDA, serum glucose and liver glycogen in normal and diabetic rats

\begin{tabular}{|c|c|c|c|c|}
\hline Groups & Control & Diabetic & $\begin{array}{l}\text { O. dillenii } \\
\text { fruit juice }\end{array}$ & $\begin{array}{c}\text { Diabetic }+ \\
\text { O. dillenii fruit juice }\end{array}$ \\
\hline Parameter & & & & \\
\hline MDA (nmol/l) & $70.85 \pm 2.74$ & $76.98 \pm 0.92^{* a}$ & $69.21 \pm 1.29$ & $71.76 \pm 1.64$ \\
\hline Gucose (mg/dl) & $116.68 \pm 1.94$ & $325.32 \pm 6.65^{* * a}$ & $111.37 \pm 2.43$ & $143.30 \pm 2.40$ \\
\hline Liver glycogen (mg/g wet liver) & $7.89 \pm 0.26$ & $7.18 \pm 0.21^{*}$ & $8.25 \pm 0.08$ & $7.49 \pm 0.13$ \\
\hline
\end{tabular}

- Each value represents the mean of 8 rats \pm SE.

- * Significant difference from control group at $p<0.05$ and $* *$ highly significant difference from control group at $\mathrm{p}<0.01$.

- a: Significant difference between diabetic group and diabetic group treated with $O$. dillenii fruit juice at $\mathrm{p}<0.05$.

Table (6): Effect of oral administration of $O$. dillenii fruit juice on serum lipids profile in normal and diabetic rats.

\begin{tabular}{|l|c|c|c|c|}
\hline \multicolumn{1}{|c|}{ Groups } & Control & Diabetic & $\begin{array}{c}\text { O. dillenii } \\
\text { fruit juice }\end{array}$ & $\begin{array}{c}\text { Diabetic }+ \text { O. } \\
\text { dillenii } \\
\text { fruit juice }\end{array}$ \\
\cline { 1 - 4 } Parameters & & & $83.13 \pm 1.27$ & $85.41 \pm 0.55$ \\
\hline TC (mg/dl) & $84.21 \pm 0.87$ & $113.55 \pm 1.62^{* * a}$ & $94.43 \pm 1.00$ & $101.48 \pm 1.73$ \\
\hline HDL-C (mg/dl) & $96.34 \pm 1.25$ & $135.09 \pm 2.81^{* * a}$ & $42.79 \pm 1.54$ \\
\hline LDL-C (mg/dl) & $19.96 \pm 1.03$ & $30.20 \pm 0.99^{* * a}$ & $45.28 \pm 0.92$ & $22.69 \pm 1.96$ \\
\hline VLDL-C (mg/dl) & $19.27 \pm 0.25$ & $56.34 \pm 2.26^{* * a}$ & $18.97 \pm 1.03$ & $20.30 \pm 0.35$ \\
\hline LDL/HDL-C ratio & $0.444 \pm 0.014$ & $1.865 \pm 0.065^{* * a}$ & $0.419 \pm 0.019$ & $0.530 \pm 0.025$ \\
\hline
\end{tabular}

- Each value represents the mean of 8 rats \pm SE.

- * Significant difference from control group at $p<0.05$ and ** highly significant difference from control group at $\mathrm{p}<0.01$.

- a: Significant difference between diabetic group and diabetic group treated with $O$. dillenii fruit juice at $\mathrm{p}<0.05$. 


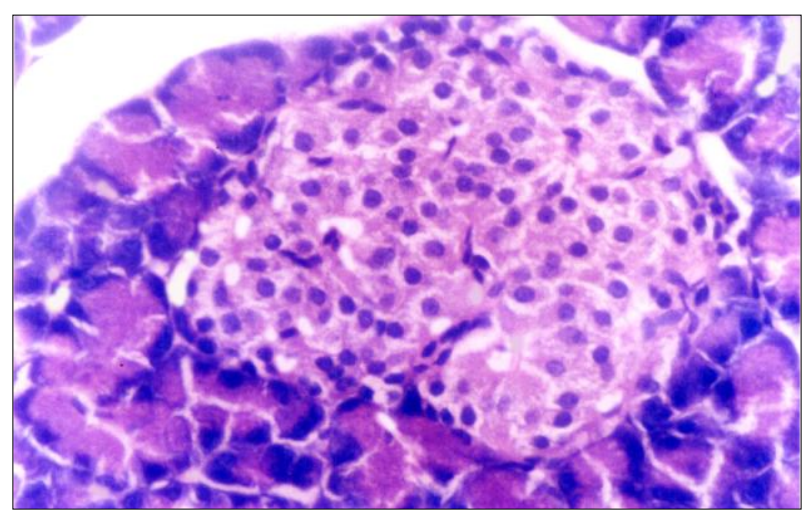

Fig. (1): Pancreas of control rats showing normal islets of Langerhans and pancreatic acini (H \& E stain x 400)

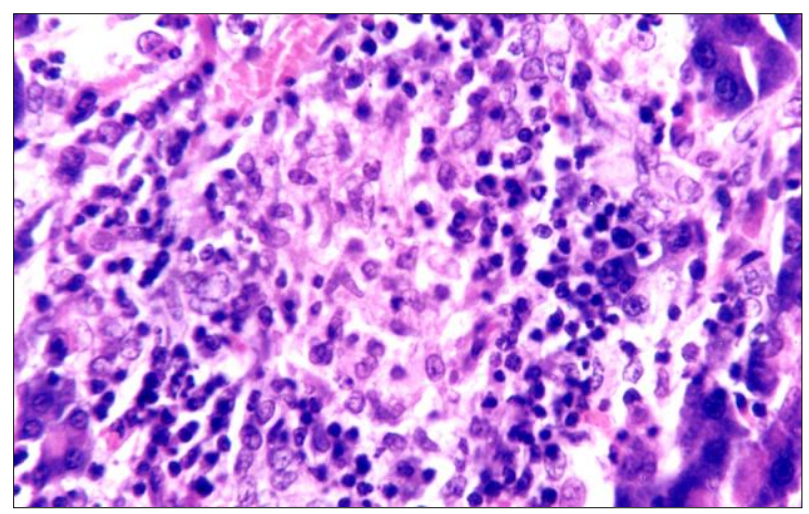

Fig. (3): Pancreas of STZ diabetic rats showing necrosis of the islets of Langerhans cells, surrounded by mononuclear inflammatory cells infiltration and congested blood vessels (H\&E stain $\mathrm{x}$ 400)

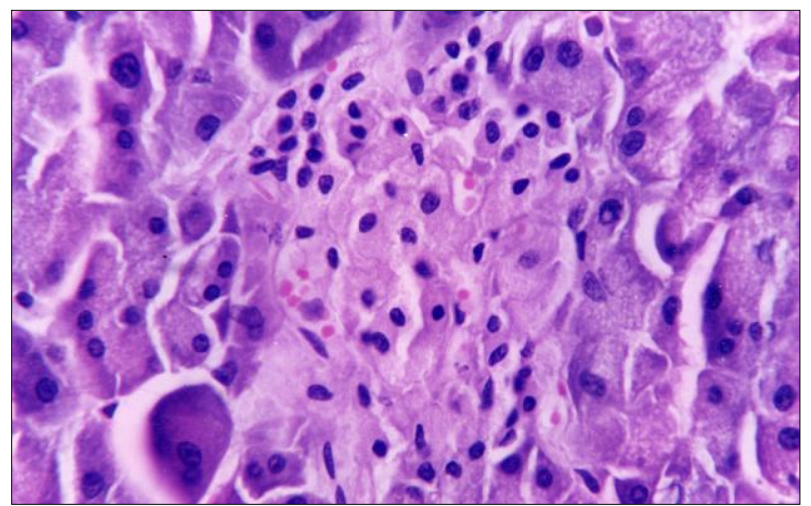

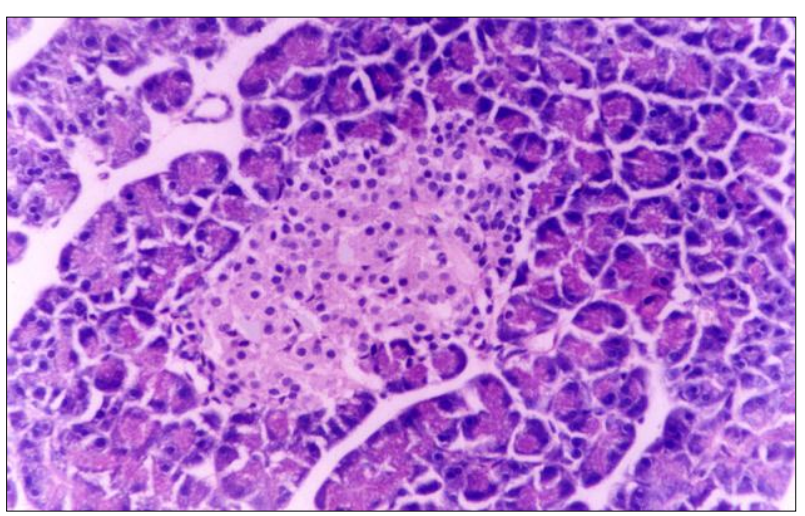

Fig. (2): Pancreas of normal rats administered $O$. dillenii fruit juice showing no histopathological changes (H\&E stain $\mathrm{x}$ 200)

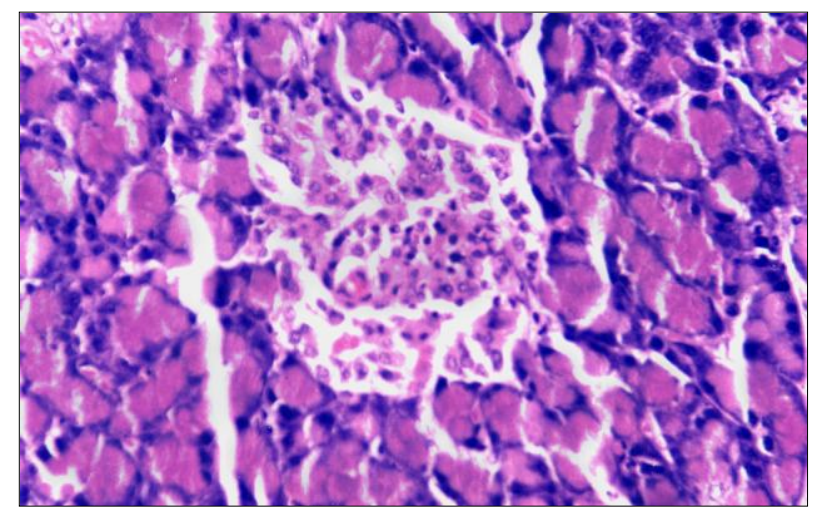

Fig. (4): Pancreas of STZ diabetic rats showing edema of the islets of Langerhans which showed necrosis and some cells showed pyknotic nuclei (H\&E stain x 400).

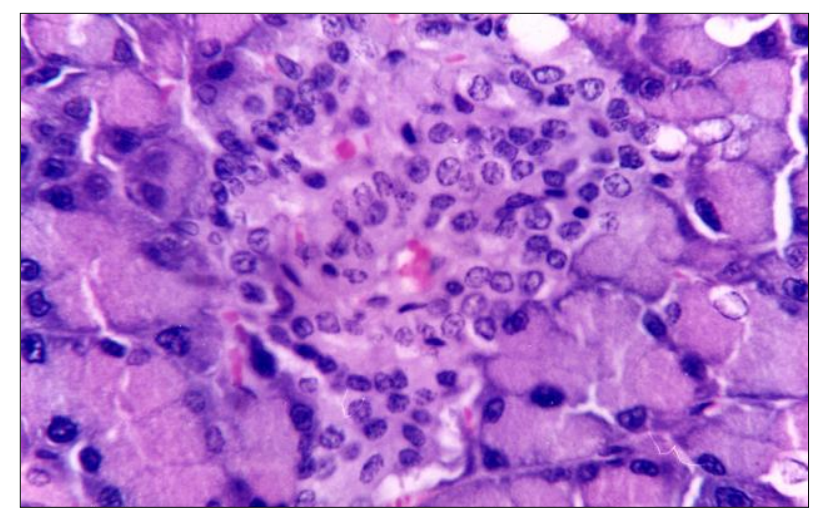

Figs. (5\&6): Pancreas of STZ diabetic rats treated with $O$. dillenii fruit juice showing that the majority of the cells consisting the islets of Langerhans were normal but few cells showing necrosis and some cells contained pyknotic nuclei (H\&E stain x 400) 


\section{Discussion}

In the present study, the chemical analysis of the edible portion of $O$. dillenii fruit revealed high percentage of fiber $(29.48 \% \pm 0.29)$ and carbabydrates $(54.38 \% \pm 0.54)$. The last values were similar to the values obtained by Ahmed et al. (2005b). Moreover, the investigated edible portion showed high contents of mineral elements. These results were in line with the resutls reported by Ahmed et al. (2005b), but higher than those reported by Díaz Medina et al. (2007) for the plant growing abroad. This variation may be due to different soils, thus the mineral content can be quite variable depending on the characteristics of the soil. In addition, the edible portion of the fruit was shown to be rich in vitamins $B_{1}, B_{2}$ and $C$. On the other hand, $\beta$ - carotene and vitamin $\mathrm{E}$ were detected in trace amounts. These results were similar to the results of Ahmed et al. (2005b), while the content of vitamin C was higher than that reported by Chang et al. (2008) for the plant growing abroad $(15.1 \pm 0.6 \mathrm{mg} / 100 \mathrm{~g}$ fresh sample). The variation may be attributed to the variety of growth condition, genetic, environmental, handling and cultural factors.

In this study, it was found that diabetic rats revealed highly significant decrease in body weight gain\% and FER, and non significant increase in food intake in diabetic group as compared with control group. The decrease in body weight in diabetic group may be attributed to different side effects of inability to use carbohydrates including lypolysis, glycogenolysis and acidosis (Ganang, 1995). In addition, Sjoslrom et al. (1998) reported that diabetes mellitus causes decrease in lipogenesis followed by increase in lipolysis, thus causes weight loss. The increase in food intake in diabetic rats may be attributed to polyphagia and polydipsia (Chen and Dawing, 1991). Treatment of diabetic rats with $O$. dillenii juice revealed noticeable improvement in body weight gain\% and FER, there were significant differences between treated and non treated diabetic groups. This finding may be explained by the results of Rahman and Zaman (1989) who reported that the fruit of O.dillenii may contain an orally active insulin-like compound, which in turn inhibits epinephrine induced lipolysis and decreased body weight.

The current study elicited marked significant elevation in the lipid peroxidation product (MDA) level in diabetic group as compared with control group. This was in accordance with the observation of Maritim et al. (2003) who reported that induction of diabetes in rats with STZ uniformly results in an increase in lipid peroxidation (MDA), an indirect evidence of intensified free radical production. Ravi et al. (2004) reported significant elevation in plasma MDA level of diabetic rats when compared to control rats. The increase in the levels of lipid peroxides in plasma generally is thought to be the consequence of increased production and liberation into the circulation of tissue lipid peroxides due to pathological changes (Selvam and Anuradha, 1990).

Concerning diabetic rats treated with $O$. dillenii juice exhibited significant improvement in MDA level as compared with non treated diabetic rats. This effect was explained by Lee and Lim (2000) who stated that the aqueous and ethanol extracts of $O$. dillenii Haw have positive roles in scavenging reactive oxidants as natural antioxidants. Butera et al. (2002) also added that the methanolic extracts of $O$. ficus indica edible pulp inhibited lipid oxidation induced by organic hydroperoxide in isolated human red blood cells and by either azo-compound-derived free radicals, or copper ions, in isolated human LDLs. In a further study made by Dok-Go et al. (2003), the isolated flavonoids, quercetin, dihydroquercetin and quercetin 3-methyl ether were reported to be the active antioxidant principles in the fruits of the $O$. ficus-indica var. saboten, exhibiting neuroprotective actions against the oxidative injuries induced in primary cultured rat cortical cells. Chang et al. (2008) also suggested that the phenolic acids and flavonoids of the methanolic extracts of $O$. dillenii Haw fruit play an important role in antioxidant activity and anti LDL peroxidation. 
The obtained results revealed marked highly significant elevation in serum glucose concentration and significant reduction in liver glycogen content in diabetic rats when compared to control rats. Administration of $O$. dillenii juice to diabetic rats ameliorated the elevation in glucose concentration and the reduction in liver glycogen content, there was significant difference in glucose concentration between treated and non treated diabetic groups. These findings were in coincidence with Abd El Razek (2004) who found highly significant hyperglycemia and decrease in liver glycogen content in alloxan diabetic group as compared with non diabetic group. The hyperglycemia and decrease in liver glycogen content in diabetic rats may be due to lack of insulin, increased gluconeogenesis and/or glycogenolysis (Defronzo and Simonson, 1992).

O.dillenii juice failed to produce hypoglycemic activity in normal rats. This was in coincidence with the observation of Perfumi and Tacconi (1996) who found that single or repeated oral doses of $O$. dillenii juice did not alter blood glucose level in normoglycemic rabbits. The hypoglycemic effect of $O$. dillenii fruit juice on diabetic rats was different from that obtained by Perfumi and Tacconi (1996), they detected the hypoglycemic effect of $O$. dillenii juice when a glucose load was given orally to diabetic rabbits. On the other hand, the antihyperglycemic effect of the fruit juice under investigation was in agreement with that reported by Afifi et al. (1996) in diabetic rats and Tao et al. (2005) in diabetic mice. The previous authors reported that oral administration of the alcoholic extract, mucilage and pectin of $O$. dillenii to the previous animals significantly decreased the blood glucose level. Phytochemical analysis of $O$. dillenii alcoholic extract showed the presence of flavonoids (Ahmed et al., 2005a), which are known to be bioactive antidiabetic principles (Rao et al., 1997). Flavonoids are known to regenerate the damaged beta cells in the alloxan diabetic rats (Chakkravarthy et al., 1980). O. dillenii fruit juice may act as hypoglycemic agent by stimulating insulin receptors of $\beta$-cells. Moreover, the antihyperglycemic activity of $O$. dillenii fruit juice may be attributed to its high content of chromium, an essential mineral involved in carbohydrate and lipid metabolism. Ample intake of chromium appears to promote insulin sensitivity and improve glycemic control (McCarty, 2005).

In the present results, diabetic rats showed highly significant elevation in TC, TAG, LDL-C and VLDL-C and LDL/HDL$\mathrm{C}$ ratio concurrent with highly significant reduction in HDL-C as compared with control group. Meanwhile, diabetic rats treated with $O$. dillenii fruit juice exhibited significant improvement in these parameters when compared with non treated diabetic group. Diabetes Mellitus is a metabolic disorder affecting carbohydrate, fat and protein metsabolism. Colca et al. (1991) reported that hypercholesterolemia, hypertriglyceridemia and reduced HDL-C levels were commonly seen in diabetes. Similar results were obtained by CameronSmith et al. (1994) who stated that STZinduced diabetic rats had elevated fasting TC and TAG levels relative to non-diabetic rats. Moreover, Kameswararao et al. (2003) found significant higher values of serum TC, TAG, LDL-C and significant lower values of HDL-C in diabetic rats compared to normal rats, which were fed the same diets. Yousri et al. (2002) suggested that increasing the level of serum TAG may be occurred as consequence of lipoprotein lipase inactivation in adipose tissue, which reduced the ability to uptake the TAG from serum leading to accumulation in serum. Fernandez et al. (2001) demonstrated that, increasing serum LDL-C level may be related to increase of intestinal absorption of lipid due to increased cholesterol synthesis and increased liver lipid synthesis. While, decreasing serum HDL-C level may be attributed to decrease of lecithincholesterol acetyl transferase (LCAT), which is responsible of estrification of cholesterol in HDL.

The therapeutic effect of $O$. dillenii juice on diabetic rats was in coincidence with the observations of Lee and Lim (2000) who found a marked statistical reduction in plasma TC, TAG, LDL-C and VLDL-C in diabetic rats after receiving the aqueous and ethanol extracts of $O$. dillenii Haw.The hypocholesterolemic action may be partly explained by the soluble fiber (pectin) 
content (Wolfram et al., 2002). The effect of pectin on serum cholesterol levels could be due to a number of factors. Of prime significance is the possibility that this effect could be mediated through its shifting the bile acids pools away from cholic acid and toward chenodeoxycholic acid. The chenodeoxycholic acid inhibits 3-hydroxy-3-methylglutary (HMG) CoA reductase (a regulatory enzyme necessary for cholesterol biosynthesis). Finally, decreased HMG CoA reductase activity results in reduced hepatic cholesterol synthesis and theoretically lower blood cholesterol concentrations (Groff and Gropper, 2000). On the other hand, Soluble fibers are usually fermented by colonic microflora producing short chain fatty acids (SCFA), which reduce serum and liver cholesterol concentrations. SCFA inhibit the synthesis of hepatic triacylglycerols and therefore reduce serum lipids (Suzuki and Kajuu, 1983 and Hara et al., 1999).

The histopathological investigation of the pancreatic tissue of STZ- diabetic rats represented the presence of necrosis, edema and congested blood vessels in the islets of Langerhans cells. Oral administration of $O$. dillenii fruit juice to STZdiabetic rats improved the previous changes, the majority of the cells consisting the islets of Langerhans tended to be normal. STZ is frequently used to induce diabetes mellitus in experimental animals through its toxic effects on pancreatic $\beta$-cells (Kim et al., (2003). The cytotoxic action of STZ is associated with the generation of reactive oxygen species causing oxidative damage (Szkudelski, 2001). The present results were in coincidence with the observations of Kanter et al. (2006) in STZ diabetic rats who found degenerative and necrotic changes and shrinking of the islets of Langerhans, the nucleus of necrotic cells indicated pyknosis. Most of the tissue damage is considered to be mediated by free radicals which attack membranes through peroxidation of unsaturated fatty acids (Stringer et al., 1989). Gul et al. (2002) reported that STZ produced oxidative stress and depletion of antioxidant systems in both blood and tissues. The findings of the fruit juice treated diabetic group indicated that $O$. dillenii fruit juice could provide protection against oxidative pancreatic tissue damage.

\section{Conclusion}

From the present results, it could be concluded that the edible portion of $O$. dillenii Haw fruit is very nutritious, being a rich source of vitamins $B_{1}, B_{2}$ and $C$ in addition to the minerals, $\mathrm{Fe}, \mathrm{Zn}, \mathrm{Cu}, \mathrm{Cr}$, $\mathrm{Mn}, \mathrm{Ca}$, and $\mathrm{Mg}$. On the other hand, the fruit juice revealed significant hypoglycemic activity in STZ induced-diabetic rats. This activity may be attributed to its antioxidant activity and its high content of chromium. Therefore, it could be recommended that $O$. dillenii should be ingested as fresh fruit to diabetic and hypercholesterolemic patients beside the usual therapy. Further investigations also should be carried out with different doses and for more prolonged periods to complete the profile of the plant in order to introduce it as a natural antidiabetic agent.

\section{Acknowledgment}

I would like to thank Mrs T.L. Youssef, Specialist of Classification and Identification of Ornamental Plants, Orman Botanical Garden, Giza, Egypt, for kindly providing the plant material. Thanks also to Prof. Dr. K.H. Al-Batanony, Professor of Taxonomy, Faculty of Science, Cairo University for kindly verifying the identification of the plant material. Finally, full gratitude is extended to Dr. Kawkab A. Ahmed, Assistant Professor of Pathology, Faculty of Veterinary Medicine, Cairo University, for helping in the histopathological study of this work

\section{References}

1. A O A C International (2000): Official Methods of Analysis of AOAC International. $17^{\text {th }}$ ed., Gaithersburg, Maryland, USA. Chap. 4. p. 21-39.

2. A O A C International (2006): Official Methods of Analysis of AOAC International. $18^{\text {th }}$ ed., Rev.1, Gaithersburg, Maryland, USA. Chap.3. p. 4,5.

3. Abd El-Razek F H (2004): Biochemical and biological changes in diabetic female rats after affected by feeding lupine (Termis) and 
locust bean pod (carob pod). Bull. Nat. Nutr. Inst., Cairo. Egypt, 24:93-120.

4. Afifi N A, El Hawary S M, Fathy M M and Sanad O A (1996): Antihyperglycemic effect of Opuntia dillenii fruit. Bull. Fac. Pharm. Cairo Univ., 34(3):189-202.

5. Ahmed A, Davies J, Randall $S$ and Skinner G R B (1996): Antiviral properties of extract of Opuntia streptacantha. Antiviral Res., 30(2/3):75-85.

6. Ahmed M S, El Tanbouly N D, Islam W T, Sleem A A and El Senousy A S (2005a): Antiinflammatory flavonoids from Opuntia dillenii (Ker-Gawl) Haw growing in Egypt. Phytother. Res., 19(9):807-809.

7. Ahmed M S, Seida A A, El-Tanbouly $\mathbf{N}$ $D$, Islam $W$ T, Sleem $A$ A and El Senousy A S (2005b): Antihyperglycemic effect and nutritive value of Opuntia dillenii (Ker-Gawl) Haw Fruits Cultivated in Egypt. Bull. NRC, Egypt. 30(2):159-177.

8. Allain $\mathbf{C} \mathbf{C}$, Poon $\mathbf{L} \mathbf{S}$, Chan $\mathbf{C}$ S, Richmond W, and Fu P C (1974): Enzymatic determination of total serum cholesterol. Clin. Chem., 20(4):470-475.

9. American Diabetes Association (2007): Standards of medical care in diabetes. Prevention and management of diabetes complications. Diabetes Care, 30 (1): S4 S41.

10. Bancroft D, Stevens $A$ and Turmer $\mathbf{R}$ (1996): Theory and practice of histological technique, $4^{\text {th }}$ ed., Churchill Living Stone, Edinburgh, London, Melbourne. p. 47-67.

11. Boyle J P, Honeycutt A A, Narayan K M, Hoerger $T \mathbf{J}$, Geiss $\mathrm{L} S$, Chen $H$ and Thompson T J T J (2001): Projection of diabetes burden through 2050: Impact of changing demography and disease prevalence in the U.S. Diabetes Care, 24:1936-1940.

12. Butera D, Tesoriere $\mathbf{L}$, Gaudio F D, Bongiorno A, Allegra M, Pintaudi A M, Kohen $R$ and Livrea $M$ A (2002): Antioxidant activities of Sicilian prickly pear (Opuntia ficus-indica) fruit extracts and reducing properties of its betalains: Betanin and indicaxanthin. J. Agric. Food Chem., 50:6895-6901.

13. Cameron-Smith D, Collier $G \mathbf{R}$ and Dea K O (1994): Effect of soluble dietary fiber on the viscosity of gastrointestinal contents and the acute glycemic response in the rat. Br. J. Nutr., 71:563-571.

14. Chakkravarthy B K, Gupta S, Gambir S $S$ and Gode K D (1980): Pancreatic beta cell regeneration. A novel antidiabetic mechanism of pterocarpus marsupium Roxb. Indian J.Pharmacol., 12:123-127.
15. Chang $\mathbf{S}$ F, Hsieh $\mathbf{C} \mathbf{L}$ and Yen $\mathbf{G} \mathbf{C}$ (2008): The protective effect of opuntia dillenii Haw fruit against low-density lipoprotein peroxidation and its active compounds. Food Chem., 106:569-575.

16. Chen V and Dawing E S (1991): Amelioration of hyperlipidemia by low fat diets in diabetic rats. Life Sci., 49:857-864.

17. Choi J, Lee C K, Lee Y C, Moon Y I, Park H J and Han Y N (2002): Biological activities of the extracts from fruit and stem of prickly Pear (Opuntia ficus-indica var.saboten). II-Effects on dietary induced hyperlipidemia. Kor. J. Pharmacog., 33(3):230-237.

18. Colca J R, Dailey C F, Palazuk B J, Hillmen R M, Dinh D M, Melchior G F and Spilman C H (1991): Lipid metabolism and diabetes mellitus. Diabetes, 40:1669.

19. Defronzo R A and Simonson D C (1992): Glucose toxicity. In: Advances in endocrinology and metabolism, vol $3^{\text {rd }}$ Lours, M.O. Mosby, p: 1-53.

20. Díaz Medina E M, Rodríguez Rodríguez E M and Díaz Romero C (2007): Chemical characterization of Opuntia dillenii and Opuntia ficus indica fruits. Food Chem., 103:38-45.

21. Dok-Go H, Lee K H, Kim H J, Lee E H, Lee J, Song Y S, Lee Y H, Jin C, Lee Y S and Cho J (2003): Neuroprotective effects of antioxidative flavonoids, quercetin, (+)dihydroquercetin and quercetin 3-methyl Opuntia ficus-indica var.saboten. BrainRes., 965(1-2):130-136.

22. Evans W C (2002): "Trease and Evans, Pharmacognosy", $15^{\text {th }}$ ed., W.B. Saundres Company Ltd., Edinburgh, London, New York. Philadelphia, Sydney, Toronto.

23. Fernandez M D, Garcia J L and Garcia F D (2001): Upper gastrointestinal toxicity of rofecoxib and naproxen. N. Engl. J. Med., 344:1398-1399.

24. Food and Nutrition Board. Instituite of Medicine (2004): Dietary Reference Intakes (DRIs): Recommended Intakes for Individuals, Vitamins and Elements. National Academy of Sciences. Available from http://www.iom.edu/Object.File/Master/ 21/372/0.pdf.

25. Fossati P and Prencipe L (1982): Serum triglycerides determined colorimetrically with an enzyme that produces hydrogen peroxide. Clin. Chem., 28:2077-2080.

26. Friedwald W T, Levy $R \quad I$ and Fredriclsor D S (1972): Estimation of the concentration of low density lipoprotein cholesterol in plasma without use of the 
preparative ultracentrifuge. Clin. Chem., 18:499-502.

27. Galati E M, Mondello M R, Giuffrida D, Dugo G, Miceli N, Pergolizzi $S$ and Taviano M F (2003): Chemical characterization and biological effects of Sicilian Opuntia ficus indica (L.) Mill. fruit Juice: antioxidant and antiulcerogenic activity. J. Agric. Food Chem., 51(17):4903-4908.

28. Ganang W F (1995): Review of medical physiology, 17th ed., Lange Med. Public, Chap.19. p. 306-326.

29. Groff J L and Gropper S S (2000): Advanced nutrition and human metabolism. Wadsworth, a division of Thomson learning, United State of American. $3^{\text {rd }}$ ed., p. 106-115.

30. Gul M, Laaksonen D E and Atalay M (2002) Effects of endurance training on tissue glutathione homeostasis and lipid peroxidation in streptozotocin-induced diabetic rats. Scand J. Med. Sci. Sports, 12:63-170.

31. Hara H, Haga S, Aoyama $Y$ and Kiriyama S (1999): Short chain fatty acids suppress cholesterol synthesis in rat liver and intestine. J.Nutr., 129:942-948.

32. Hassid W $T$ and Abraham $S$ (1957): Determination of glycogen and starch. In "Method in Enzymology". Colowick, S.P. and Kaplan, N.O. (eds.), Academic Press, New York, p.43.

33. Kameswararao B, Kesavulu $M$ M and Apparao C (2003): Evaluation of antidiabetic effect of Momordica cymbalaria fruit in alloxan-diabetic rats. Fitoter., 74(1-2):7-13.

34. Kanter M, Uysal $H$ and Karaca $T$ (2006): Depression of glucose levels and partial restoration of pancreatic $\beta$-cell damage by melatonin in streptozotocin-induced diabetic rats. Arch.Toxicol., 80:362-369.

35. Kim M J, Ryu G R, Chung J S, Sim S S, Min Dos Rhie D J, Yoon S H, Hahn S J, Kim M S and Jo Y M (2003): Protective effect of epicatechin against the toxic effects of STZ on rat pancreatic islets: in vivo and in vitro. Pancreas, 26:292-299.

36. Kitts D D, Wijewickreme A $\mathbf{N}$ and $\mathbf{H u} \mathbf{C}$ (2000): Antioxidant properties of a North American ginseng extract. Mol. Cell. Biochem., 203:1-10.

37. Lee J C and $\operatorname{Lim} \mathbf{K} \mathbf{T}$ (2000): Effect of cactus and ginger extracts as dietary antioxidant on reactive oxidant and plasma lipid level. Food. Sci. Biotechnol., 9:83-88.

38. Lopes-Virella M F, Stone S, Ellis S and Collwell J A (1977): Cholesterol determination in high-density lipoproteins separated by three different methods. Clin. Chem., 23(5):882-886.

39. Loro J F, del Rio I and Pérez-Santana $\mathbf{L}$ (1999): Preliminary studies of analgesic and anti-inflammatory properties of Opuntia dillenii aqueous extract.J. Ethnopharmacol., 67:213-218.

40. Lutz W and Pardridge M (1993): Insulin therapy normalizes glucose transporter mRNA but not immunoreactive transporter protein in streptozotocin diabetic rats. Metabolism, 42(8):939-944.

41. Maritim A C, Sanders R A and Watkins J B (2003): Diabetes, oxidative stress and antioxidants. J. Biochem. and Mol. Toxicol., 17(1):24-38.

42. McCarty M (2005): Nutraceutical resources for diabetes prevention: an update. Med. Hypotheses, 64:151-158.

43. National Food Agency of Denmark (1996a): Ministry of Health Institute of Food Chemistry and Nutrition. Determination of vitamin $B_{1}$ and $B_{2}$ by HPLC in Food and Feed method No.189.2.

44. National Food Agency of Denmark (1996b): Ministry of Health Institute of Food Chemistry and Nutrition. Determination of vitamin C by HPLC in Food and Feed method No.113.2.

45. National Food Agency of Denmark (1996c): Ministry of Health Institute of Food Chemistry and Nutrition. Determination of vitamin $\mathrm{A}$ and $\mathrm{E}$ by HPLC in Food and Feed method No.AF255.1.

46. National Food Agency of Denmark (2001): Ministry of Health Institute of Food Chemistry and Nutrition. Determination of vitamin D3 by HPLC in Food and Feed method No. AF172.2.

47. Park E H, kahng J H, lee $\mathbf{S} \mathbf{H}$ and Shin $\mathbf{K}$ H (2001): An anti-inflammatory principle from cactus. Fitoter., 72 (3):288-290.

48. Perfumi $M$ and Tacconi $R$ (1996): Antihyperglycemic effect of fresh Opuntia dillenii fruit from Tenerife (Canary Islands). Inter. J. Pharmacog., 34(1):41-47.

49. Peschke E, Ebelt H, Bromme $\mathbf{H} \mathbf{J}$ and Peschke D (2000): Classical and new diabetogens: Comparison of their effects on isolated rat pancreatic islets in vitro. Cell Mol. Life Sci., 57(1):158-164.

50. Petrovsky N and Schatz D A (2003): The immunology of human type 1 diabetes. In Textbook of Diabetes 1. Volume 1. $3^{\text {rd }}$ ed., Pickup, J.C. and Williams, G. (eds.), London, Blackwell Science Ltd, p. 18.118.14.

51. Rahman A U and Zaman K (1989): Medicinal plants with hypoglycemic activity J. Ethnopharmacol., 26:1-55. 
52. Rao B K, Giri R, Kesavulu M M and Apparao C H (1997): Herbal medicine in the management of diabetes mellitus. Manphar Vaidhya Patrica., 1(4):33-35.

53. Rates S M (2001): Plants as a source of drugs.Toxicon., 39(5):603-613.

54. Ravi K, Ramachandran $B$ and Subramanian S (2004): Effect of Eugenia Jambolana seed kernel on antioxidant defense system in streptozotocin-induced diabetes in rats. Life Sci., 75: 2717-2731.

55. Reeves $\mathbf{P}$ G, Nielsen $\mathbf{F} \mathbf{H}$ and Fahey $\mathbf{G} \mathbf{C}$ (1993): AIN-93 Purified diets for laboratory rodents: Final report of the American Institute of Nutrition Ad Hoc Writing. Committee on the Reformulation of the AIN-76. A Rodent diet. J. Nutr., 123:1939-1951.

56. Ross J H (1976): "Flora of Southern Africa". Cape, \& Transvaal printers, Ltd., Parow, C.P., South Africa, 22, 149-155.

57. Saenz C (2002): Cactus pear fruits and cladodes: a source of functional components for foods. Acta. Horticult., 581:253-263.

58. Saleem R, Ahmad M, Azmat A, Ahmad S I, Faizi Z, Abidi $L$ and Faizi $S$ (2005): Hypotensive activity, toxicology and histopathology of opuntioside-I and methanolic extract of Opuntia dillenii. Biol. Pharm. Bull., 28(10): 1844-1851.

59. Selvam R and Anuradha C V (1990): Effect of oral methionine on blood lipid peroxidation and antioxidants in alloxaninduced diabetic rats. J. Nutrit. Biochem., $1: 653-658$

60. Sjoslrom I, Rissomen A, Anderson T and Boldrin M (1998): Randomized placebo controlled trial of orlistat for weight loss and prevention of weight regain in obese patients. Lancet, 352:167-172.

61. Snedecor G.W. and Cochron, W.G. (1989). Statistical methods. $8^{\text {th }}$ ed., Lowa State Univ. Press, Ames, Lowa, USA.

62. Stringer M D, Gorgo P G, Freeman A and Kakkar V V (1989): Lipid peroxides and atherosclerosis. Braz. Med. J., 298:281284.
63. Suzuki $M$ and Kajuu $T$ (1983): Suppression of hepatic lipogenesis by pectin and galacturonic acid orally-fed at the separate timing from digestionabsorption of nutrient in rats. J. Nutr. Sci. Vitaminol., 29:553-562.

64. Szkudelski T (2001): The mechanism of alloxan and streptozotocin action in $\beta$-cells of the rat pancreas. Physiol. Res., 50:537546.

65. Tao M H, Zeng F H, Lu X Y and Zhang W M (2005): Hypoglycemic acitivity of Opuntia dillenii polysaccharides. J. Hum. Agric. Univ., 31(6):612-615.

66. Trinder P (1969): Determination of blood glucose using 4-Aminophenazone. J. Clin. Path., 22:246.

67. Wild S, Roglic G, Green A, Sicree R and King H (2004): Global prevalence of diabetes: estimates for the year 2000 and projections for 2030. Diabetes Care, 27:1047-1053.

68. Wolfram R M, Kritz H, Efthimiou Y, Stomatopoulos J and Sinzinger $H$ (2002): Effect of prickly pear (Opuntia robusta) on glucose and lipid metabolism in non diabetics with hyperlipidemia-a pilot study. Wien- Klin- Wochenschr, 114 (19-20): 840-846.

69. Yoshioka T, Kawada K, Shimad A T and Mori M (1979): Lipid peroxidation in maternal and cord blood and protective mechanism against activated oxygen toxicity in the blood. Am. J. Obstet. Gynecol., 135:372-376.

70. Yousri R M, Mohamed M M, Teleb Z A, Ibrahim N K, Mohamed T E and Ali F T (2002): Treatment of some biochemical disorders in experimental irrigated rats with non-steroidel anti-inflammatory drugs and/or anabolic agent. The Egypt. J. Biochem. \& Mol. Biol., 20(1):31-46.

71. Zomlefer W B (1994): Guide to flowering Plant Families, The University of North Carolina Press, Chapel Hill \& London, 5861. 
Inas Z.A. Abdallah

\section{تقييم مدى فاعلية عصير ثمار فاكهة Opuntia dillenii (نوع من أنواع التين

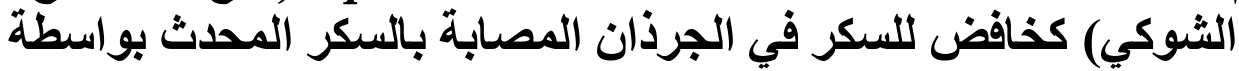 \\ الإستربتوزوتوسين \\ إيناس زيدان عبده عبد الله \\ قسم التغذية و علوم الأطعمة ـ كلية الاقتصاد المنزه لئي - جامعة حلو الن}

الملخص: تنتخدم فاكهة Opuntia dillenii وهي نوع من أنواع التين الثوكي في الطب الثنعبي

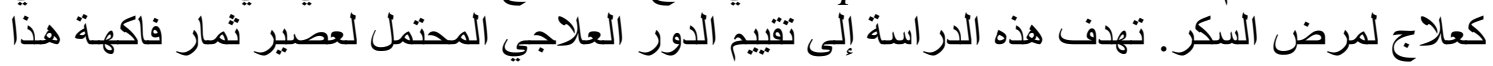

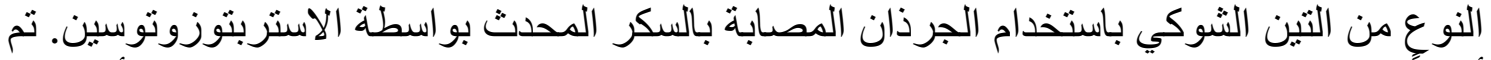

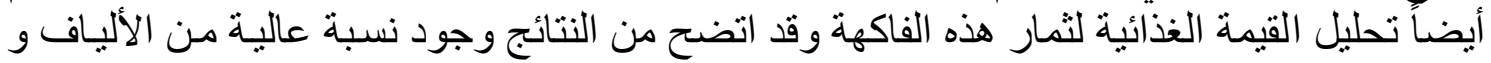

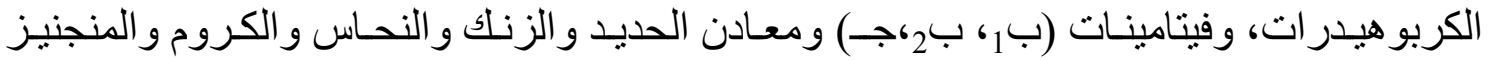

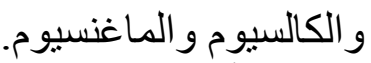

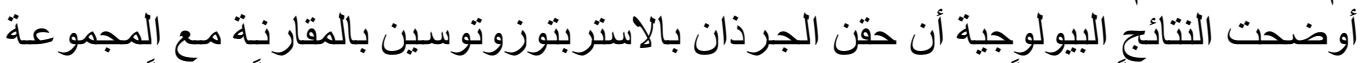

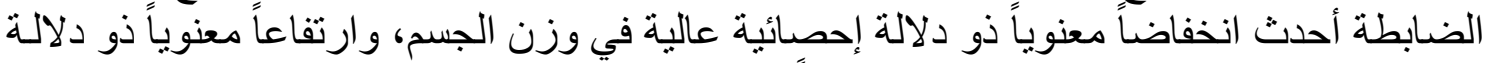

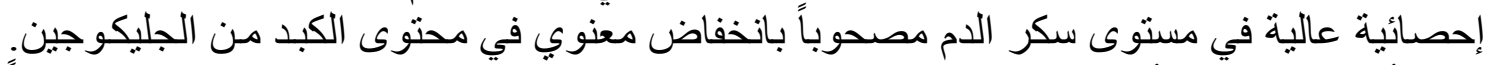

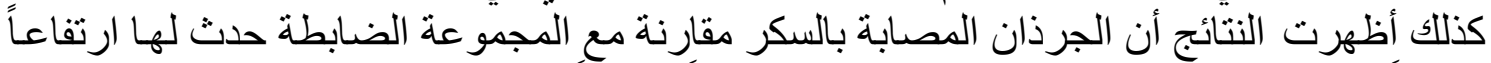

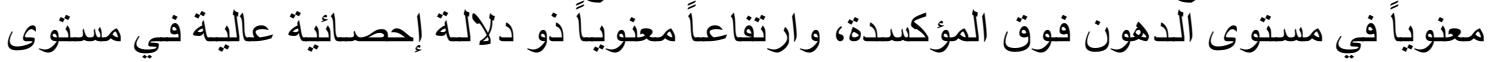

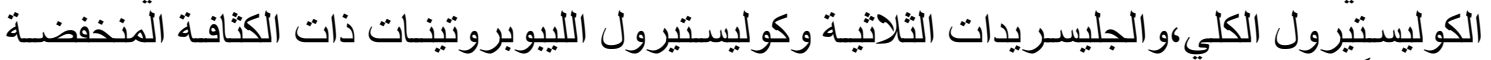

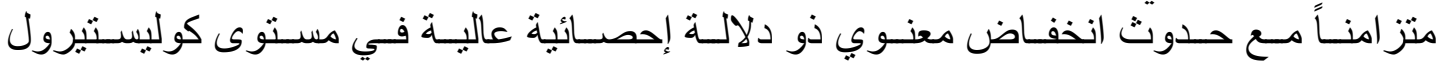
الليبوبروتينات ذات الكثافة العالية.

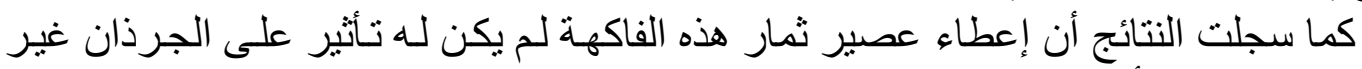

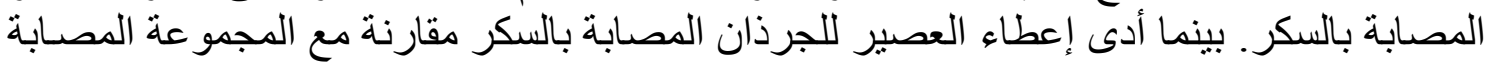

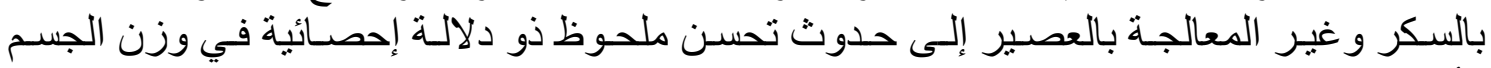
و أيض الدهون، و انخفاض ملحوظ ذو دلالة إحصائية في مستوى سكر الدم ومستوى الدهون فلدون فوق أوضحت الدر اسات الهستوباتولوجية لأنسجة البنكرياس للجرذان المصابة بمرض السكري المؤكسدة.

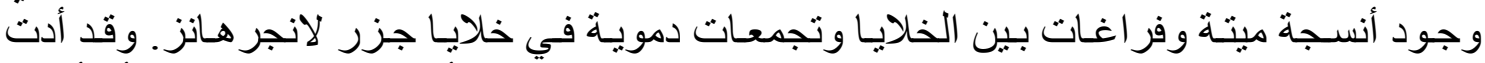

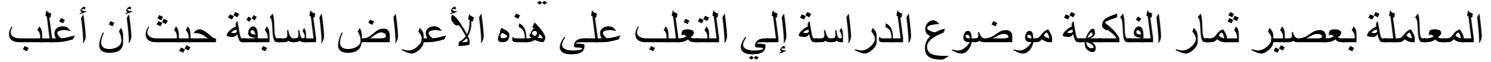

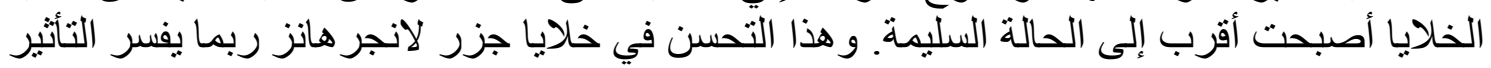

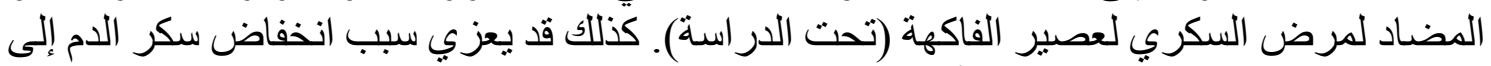

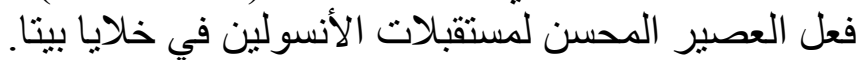

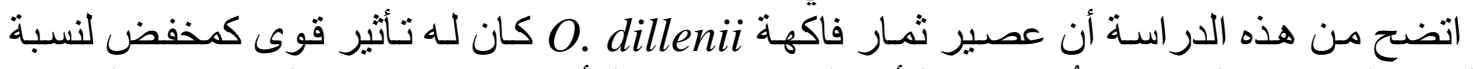

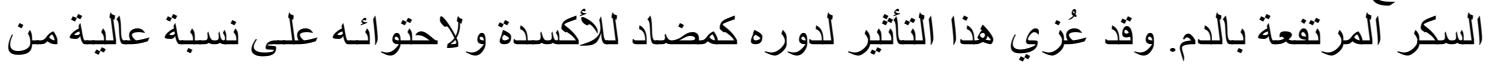

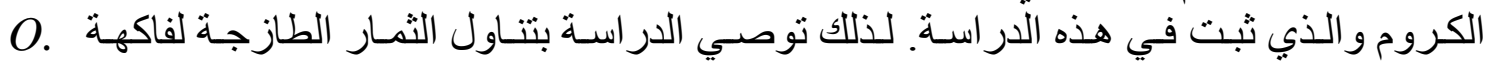

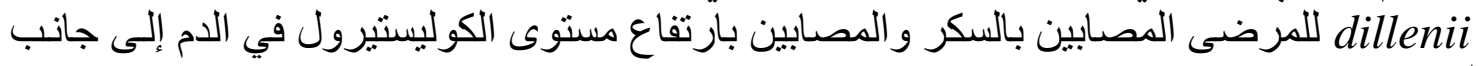
العلاج الاعتيادي. 